\title{
PEMANFAATAN e-WOM DALAM KEGIATAN KOMUNIKASI PEMASARAN \\ PRODUK ES KRIM AICE
}

\author{
IRAWATI SRI WULANDARI \\ Magister Ilmu Komunikasi, Universitas Diponegoro \\ Email: irawati.swulandari@gmail.com
}

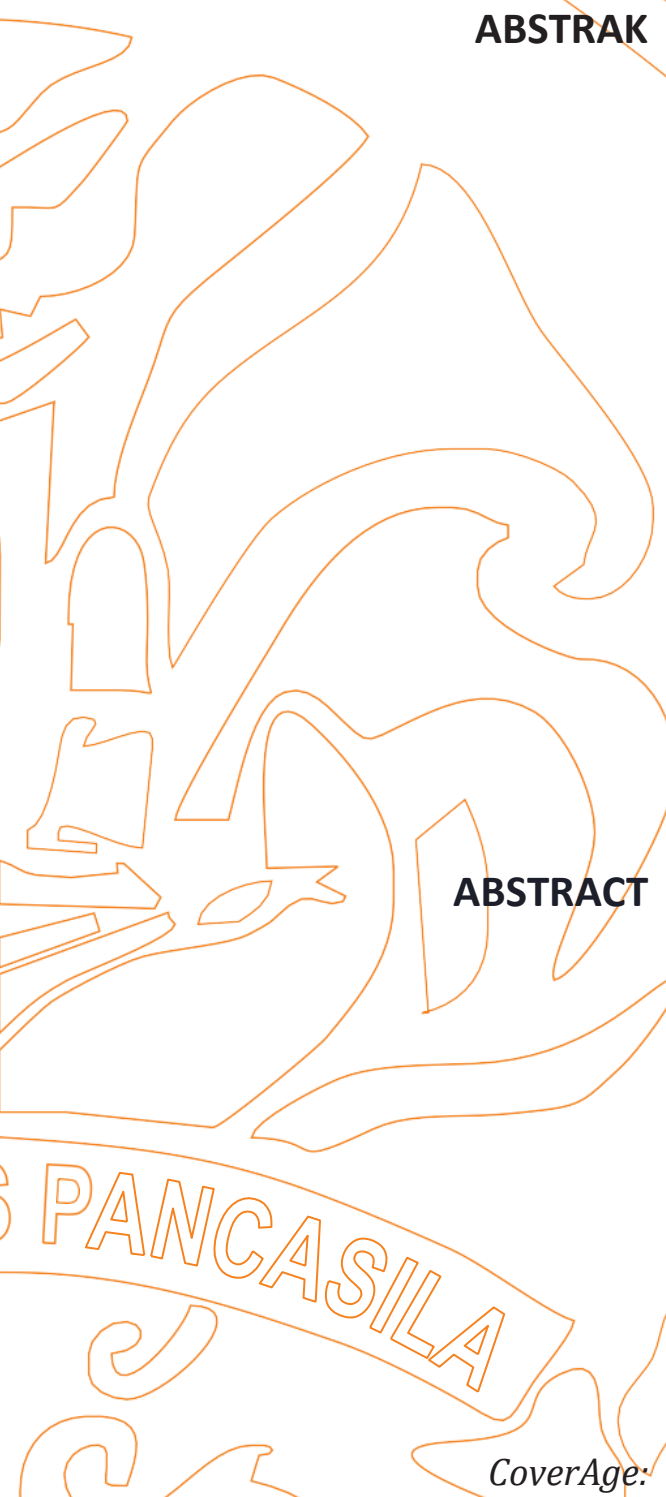

Journal of Strategic

Communication

Vol. 11, No. 1, Hal. 46-50.

September 2020

Fakultas flmu Komunikasi, Universitas Pancasila

Pertumbuhan industri es krim di Indonesia sedang mengalami kemajuan yang pesat sejak empat tahun terakhir. Aice sebagai produsen baru di industry es krim Indonesia mulai beredar di Indonesia sejak tahun 2015. Sejumlah sertifikat dan penghargaan yang didapatkan Aice menunjukkan bahwa Aice mampu mengejar dan bahkan mengungguli merek lain yang sudah lama beredar di masyarakat. Tujuan penelitian ini untuk mendeskripsikan kegiatan e-WOM yang dilakukan es krim Aice. Penelitian ini menggunakan pendekatandeskriptif kualitatif untuk menggambarkan bagaimana kegiatan e-WOM yang dilakukan Aice dalam upaya untuk meraih kepercayaan konsumen sehingga Aice mampu mendapatkan TOP Brand di tahun 2019. Studi ini menemukan bahwa strategi marketing komunikasi yang dilakukan oleh es krim Aice menggunakan e-WOM melalui Instagram @aiceindonesia dilakukan untuk memenuhi lima tujuan umum dari social media marketing, yaitu relationship building, brand building, publicity, promotions, dan market research.

Kata Kunci: e-WOM, Komunikasi Pemasaran, Aice.

The growth of the ice cream industry in Indonesia is experiencing rapid progress since the last four years. Aice as a new producer in the Indonesian ice cream industry began to circulate in Indonesia since 2015. A number of certificates and awards obtained by Aice show that Aice is able to pursue and even surpass other brands that have long been circulating in the community. The purpose of this study is to describe the e-WOM activities conducted by Aice ice cream. This study uses a qualitative descriptive approach to describe how e-WOM activities carried out by Aice in an effort to gain consumer trust so that Aice is able to get the TOP Brand in 2019. This study found that the marketing communication strategy carried out by Aice ice cream uses e-WOM through Instagram @ aiceindonesia is done to fulfill the five general objectives of social media marketing, namely relationship building, brand building, publicity, promotions, and market research.

Keywords: e-WOM, Marketing Communications, Aice.

.




\section{PENDAHULUAN}

Pertumbuhan industry es krim di Indonesia sedang mengalami kemajuan yang pesat sejak empat tahun terakhir. Aice sebagai produsen baru di industry es krim Indonesia mulai beredar di Indonesia sejak tahun 2015. Pada awal kemunculannya es krim Aice sempat diterpa kabar miring bahwa es krim Aice hanya mengandung bahan kimia tanpa kandungan buah asli. Tetapi Aice membantah informasi tersebut dengan menyebarkan sertifikat BPOM dan Halal MUI dengan kategori sangat baik/ excellent. Kemudian Aice juga mendapatkan banyak penghargaan lainnya, hingga tahun 2019 Aice berhasil mendapatkan TOP Brand For Kids2019 bersama dua merek es krim lainnya yaitu Walls dan Campina. Aice menunjukkan bahwa Aice mampu mengejar dan bahkan mengungguli merek lain yang sudah lama beredar di masyarakat. Prestasi yang dimiliki oleh Aice tentunya sangat mengejutkan, karena Aice merupakan produk yang dikenal karena harganya yang sangat murah dibandingkan kompetitor, yaitu antara $\mathrm{Rp} 2.000$ sampai $\mathrm{Rp}$ 10.000. Harganya yang tergolong sangat murah untuk es krim dengan bentuk dan rasa yang sangat unik di awal kemunculannya membuatnya langsung booming di kalangan masyarakat.

Penerapan strategi e-WOM sudah menjadi jamak dilakukan oleh suatu perusahaan untuk melakukan kegiatan komunikasi pemasarannya terutama pada era digital saat ini. e-WOM adalah pembicaraan positif maupun negative tentang suatu produk melalui internet. e-WOM menurut Henning-Thurau et al. (2004:39) merupakan pernyataan negatif atau positif yang dibuat oleh konsumen aktual, potensial, atau konsumen sebelumnya mengenai produk atau perusahaan dimana informasi ini tersedia bagi orang-orang ataupun institusi melalui media internet. e-WOM secara tidak langsung menjadi strategi suatu perusahaan untuk menjaga dan mengontrol citranya agar tetap baik di dunia maya dan membantu memberikan pandangan baru bagi para pelaku bisnis dalam upaya pemasaran produk dan jasa. Marketing komunikasi menggunakan e-WOM juga cocok digunakan untuk bisnis baru sebagai pengenalan produk dan pembentukan brand awereness kepada masyarakat seperti yang dilakukan es krim Aice.

Strategi e-WOM yang digunakan Aice yaitu melalui website dan media sosial. media sosial yang digunakan Aice antara lain Facebook,
Twitter, Instagram, dan Youtube. Peneliti memfokuskan strategi e-WOM yang dilakukan es krim Aice melalui Instagram karena dari semua strategi e-WOM yang digunakan, setelah penulis melakukan pencarian di website socialblade.com, Instagram adalah yang paling banyak follower dan paling banyak aktivitasnya, sehingga konten apa yang ada di instagram @aiceindonesia selalu mendapatkan respon yang sangat baik, dibuktikan dengan jumlah upload gambar yang tinggi sebanyak 578 postingan, rata-rata comment per postingan 46,44 , dan rata-rata like per postingan 581,16 . Karena tingginya aktivitas e-WOM di Instagram @aiceindonesia maka Instagram @aiceindonesia juga menjadi penunjuk kredibilitas atau citra perusahaan, sehingga konten apa yang ada di Instagram Aice mempengaruhi sifat pesan e-WOM yang akan tersebar.

Tujuan penelitian ini adalah untuk mendeskripsikan strategi marketing komunikasi es krim Aice melalui e-WOM yang dilakukan oleh Aice.

\section{TINJAUAN PUSTAKA}

\section{Bauran Komunikasi Pemasaran}

Menurut Kotler dan Armstrong (2012:476) komunikasi pemasaran adalah sarana yang digunakan oleh perusahaan dalam upaya untuk menginformasikan, membujuk, dan mengingatkan konsumen baik secara langsung maupun tidak langsung tentang produk dan merek yang mereka jual. Menurut Kotler dan Armstrong (2012:478), bauran komunikasi pemasaran terdiri atas delapan cara komunikasi utama yaitu: advertising, sales promotion, events and experiences, public relations and publicity, direct marketing, interactive marketing, personal selling, dan word-of-mouth marketing.

\section{Electronic Word of MouthMarketing}

Pesatnya kemajuan teknologi khususnya pada jaringan internet, memungkinkan adanya sebuah komunikasi WOM yang tidak hanya menjadi sebuah bentuk komunikasi perseorangan, tapi dilakukan melalui media online yang disebut electronic Wordof-Mouth (e-WOM).

e-WOM menurut Henning-Thurau et al. (2004:39) merupakan pernyataan negatif atau positif yang dibuat oleh konsumen aktual, potensial, atau konsumen sebelumnya mengenai produk atau perusahaan dimana informasi ini tersedia bagi orang-orang ataupun institusi melalui media internet. 
Menurut Chatterjee dalam Jalilvand dan Samiei (2012:2) penggunaan internet dan jejaring social yang meningkat merupakan hal yang penting dimana saat ini word of mouth tidak hanya dilakukan perorangan namun bisa dalam bentuk apa saja termasuk internet yang disebut dengan eWOM. Efektivitas dari e-WOM lebih baik dibandingkan dengan komunikasi WOM di dunia offline, karena aksesibilitas yang lebih besar dan jangkauan yang tinggi (Jalilvand, 2012:466).

Menurut Jeong dan Jang (2011:360) perbedaan antara WOM tradisional dengan eWOM antara lain sebagai berikut:

1.WOM dilakukan dengan bertatap muka secara langsung, sedangkan e-WOM secara online. Adanya kemajuan teknologi merubah jenis komunikasi langsung dengan tatap muka menjadi komunikasi pada dunia maya.

2. WOM dilakukan secara terbatas sedangkan eWOM aksesbilitasnya tinggi. e-WOM dapat menjangkau semua orang yang mengakses internet.

3. e-WOM memungkinkan pengguna website dan media social mengembangkan hubungan virtual dengan konsumen atau kelompok lain.

4.e-WOM di posting atau diakses anonim secara online atau orang yang tidak dikenal, sedangkan WOM tradisional memiliki tingkat kredibilitas yang tinggi, percakapan langsung dengan orang yang dikenal.

5. Tingkat kepercayaan penerima informasi WOM lebih tinggi karena didukung dengan bahasa tubuh dan intonasi suara, sedangkan e-WOM tidak.

Goldsmith et al. menyatakan e-WOM mempunyai beberapa tipe dan masing-masing memiliki karakteristik yang berbeda (Basarani, 2011:14) diantaranya one-to-one (seperti e-mail dan instant message), one-to-many (seperti website, product review, chatroom), dan many-tomany (seperti blog, virtual communities, news group).

\section{Media sosial}

Media sosial saati ini menjadi suatu gaya hidup masyarakat untuk dapat besosialisasi dengan orang-orang yang terhubung dalam suatu komunitas tertentu. Jaringan media sosial ini merupakan bentuk baru dari dialog antara "customer-to-customer" dan "business-toconsumer" yang memiliki implikasi besar terhadap pemasar (Kotler \& Amstrong, 2012:141). Media sosial berguna memberikan individu kemampuan untuk menetapkan profit pribadi, terhubung dengan pengguna lain, membuat, menerbitkan dan merespon content (Tom Funk, 2011:8). Media sosial juga menjadi sarana komunitas online dimana orang dapat bersosialisasi dan bertukar informasi yang bertujuan membangun hubungan dan membangun loyalitas pada konsumen (Joseph, 2011:27). Pengguna media sosial berbicara tentang merekomendasikan atau membeli suatu produk setelah mereka terlibat dengan perusahaan melalui media sosial (Mathis dan Jackson, 2011).

Kelebihan dari media sosial adalah dapat membangun komunikasi dua arah, yaitu dapat mendengar apa yang menjadi aspirasi dan pikiran konsumen. Dalam media sosial tedapat tiga aktivitas yang dapat dilakukan (Joseph, 2011:27) yaitu:

1. Social media maintenance

Social media maintenance yaitu merawat media sosial dengan melakukan posting secara rutin dalam media social serta melakukan interaksi dengan membalas komentar dari anggota. Dalam hal ini harus ada tim kecil yang bertanggung jawab dalam melakukan posting rutin dan menghapus komentar yang kurang baik.

2. Social media endorsement

Social media endorsement yaitu mencari public figure yang memiliki penggemar yang sangat banyak dan memberikan dukungan terhadap media social yang dimiliki perusahaan. Dalam memilih endorses harus disesuaikan bidangnya dengan produk perusahaan.

3. Social media activation

Social media activation yaitu membuat kegiatan yang unik sehingga dapat menciptakan WOM. WOM akan meningkatkan perhatian terhadap produk perusahaan secara signifikan.

\section{METODE}

Penelitian ini merupakan studi kualitatif deskriptif-evaluatif dengan menggunakan metode atau pilihan kajian studi kasus. Metode deskriptif bertujuan melukiskan secara sistematis fakta atau karakteristik populasi tertentu atau bidang tertentu secara factual dan cermat. Menurut Bodgan dan Taylor dalam Moleong (2008:5), penelitian deskriptif kualitatif merupakan penelitian yang menghasilkan data deskriptif berupa kata-kata tertulis atau lisan dari orang dan perilaku yang dapat diamati.

Menurut Rossi dan Freeman, penelitian evaluatif adalah penerapan prosedur penelitian 
social yang sistematis dalam rangka menilai konseptualisasi, desain, implementasi dan kegunaan sebuah program intervensi social. Sedangkan penelitian evaluative menurut Suchman yaitu suatu penentuan (apakah berdasarkan opini, catatan, data subyektif, atau obyektif), hasil yang diperoleh dari beebrapa kegiatan pada suatu program yang dibuat untuk memperoleh suatu tujuan tentang nilai dan performance.

Pendekatan yang digunakan dalam penelitian ini adalah studi kasus. Menurut Mulyana (2004:201) studi kasus adalah uraian dan penjelasan komprehensif mengenai berbagai aspek seorang individu, suatu kelompok, suatu organisasi atau suatu program, atau situasi social. Metode studi kasus bagi kalangan periset, menurut Robert E. Stake (1995(236), bertujuan untuk mengoptimalkan pemahaman melalui pertanyaan riset akademis.

Penggunaan studi kasus pada penelitian ini maka akan diperoleh serangkaian pemikiran yang mengarah pada kesimpulan dari mengapa suatu keputusan diambil, bagaimana prosesnya dan selanjutnya bagaimana hasilnya. Berdasarkan hal tersebut maka dalam penelitian ini akan dideskripsikan data yang diperoleh dari subyek penelitian yaitu produk es krim Aice dan diarahkan pada kesimpulan terkait pengambilan keputusan kebijakan pemilihan konsep e-WOM untuk memenuhi lima tujuan dari social media marketing menurut Guneluis (Gunelius, 2011:15) yaitu relationship building, brand building, publicity, promotions, dan market research.

Dalam penelitian ini, peneliti melakukan pengumpulan data dengan mengumpulkan dokumen dan wawancara mendalam dengan informan melalui proses tanya jawab secara langsung, studi pustaka, serta dokumentasi audio dan visual.

\section{HASIL DAN PEMBAHASAN}

\section{Mendefinisikan Strategic Communication}

Komunikasi WOM terjadi ketika konsumen memberikan saran atau pendapat dan berbagi pengalaman kepada konsumen lain tentang sebuah produk, jasa atau merek (Schiffman dan Kanuk, 2010). Berdasarkan sifatnya, e-WOM dapat dikategorikan positif dan negatif. Sebisa mungkin perusahaan dapat mendorong penyebaran e-WOM yang positif dan menekan atau bahkan menghilangkan e-WOM negatif yang dapat berdampak buruk atau kontra produktif bagi tercapainya sasaran pemasaran.

e-WOM adalah sebuah media komunikasi untuk saling berbagi informasi mengenai suatu produk atau jasa yang telah dikonsumsi antar konsumen yang tidak saling mengenal dan bertemu sebelumnya (Gruen, 2006:6). Dalam Instagram @aiceindonesia setiap postingan gambar berbentuk animasi dengan warna warni ceria yang diharapan mampu menarik perhatian follower.

Beberapa tindakan yang dapat diadopsi untuk meningkatkan WOM menurut Peters, Morris, Heckman, dan Dye (Mason, 2008:89):

1. Buat agar produk berada dalam tangan konsumen yang serba tahu atau penyebar berita. Contohnya adalah Follower Instagram @aiceindonesia sering mengunggah es krim yang dibelinya di instastory, dan kemudia direpost oleh Instagram @aiceindonesia. Selain itu, Aice juga sering mengadakan giveaway di instagramnya dengan permintaan upload produk Aice di feed Instagram follower, serta mention kepada teman-teman follower. Dengan cara tersebut, otomatis follower Instagram @aiceindonesia telah melakukan penyebaran berita.

2. Gunakan pemimpin opini atau selebritas sebagai penyampai pesan.

Contoh yang pernah dilakukan Aice adalah Aice sering menggunakan selebritas dan food influencer di Instagram. Contohnya adalah Julian Jacob sebagai presenter di acara Surprise Net TV yang merupakan acara Aice dengan tema menyebarkan kebaikan, selebgram Londo Kampung yang melakukan tour keliling pabrik es krim Aice, Baim Wong, Febby Rastanty, Jessica Iskandar, dan masih banyak lagi.

3. Berikan produk secara luas dan gratis, atau dengan harga murah pada ahli industry, tokoh masyarakat, dan pemimpin opini.

Contohnya adalah pada saat Aice mengunjungi panti asuhan YPAC, Aice membagikan es krim serta bantuan kepada panti tersebut. Aice juga memecahkan rekor MURI dengan mencatat Pembagian Es Krim Secara Serentak di Kota Terbanyak di Indonesia pada tanggal 28 Mei 2019.

4. Pelihara pengguna awal dan berikan insentif penjualan kepada mereka.

Contohnya adalah Aice sering mengadakan giveaway di instagramnya yang ditujukan kepada follower serta konsumen setianya.

5. Berikan contoh produk dan perlihatkan pada berbagai pertemuan, sekolah, dan pusatpusat komunitas.

Contoh yang pernah dilakukan Aice adalah Aice memberikan sample produknya 
secara gratis saat pembukaan dan penutupan acara Asian Games 2018 kepada para penonton saat akan memasuki venue. Selain itu, dalam kesempatan Asian Games 2018, Aice juga menyediakan banyak frezzer yang penuh berisi es krim Aice untuk para atlet yang akan bertanding.

6. Tawarkan wisata di pabrik perusahaan kepada anak-anak sekolah, klub, konsumen.

Aice telah membuka pabriknya yang berlokasi di Mojokerto untuk umum. Cara pendaftarannya sangat mudah karena hanya dengan mengisi data di website Aice dan kemudian menunggu untuk dihubungi pihak Aice untuk jadwal kunjungannya.

Menurut Guneluis (Guneluis, 2011:15) ada lima tujuan paling umum dari social media marketing, yaitu:

\section{Relationship building (membangun hubungan)}

Manfaat utama dari pemasaran media sosial adalah kemampuan untuk membangun hubungan dengan konsumen yang terlibat secara aktif, teman sebaya, dan yang lainnya. Aice membuktikan bahwa relationship building berjalan dengan baik, dibuktikan dengan banyaknya comment dan like di setiap postingannya di Instagram @aiceindonesia, serta banyaknya peserta di setiap giveaway yang dilakukan. Aice selalu memberikan caption dengan bahasa non-formal yang juga digunakan oleh anak muda dan kata-kata yang menarik. Sehingga followernya pun merasa enjoy dalam meninggalkan comment di setiap postingannya. Selain itu, admin dari Instagram @aiceindonesia juga selalu aktif memberikan jawaban dari pertanyaan followernya.

2. Brand building (membangun merek)

Percakapan di media sosial adalah langkah awal yang sempurna untuk meningkatkan brand awareness, meningkatkan brand recognition dan recall, serta meningkatkan brand loyalty. Dengan terjalinnya relationship building yang baik dan aktif serta positif, tentu brand building pun akan ikut berjalan dengan baik.

\section{Publicity (publisitas)}

Pemasaran media sosial menyediakan tempat dimana perusahaan dapat berbagi informasi dengan konsumennya. Aice selalu berbagi setiap informasi promosi penjualan, kegiatan sponsorship yang dilakukan, konten acara Surprise Net TV, dan lainnya kepada konsumen, sehingga konsumen tidak pernah ketinggalan berita mengenai apa saja yang telah dilakukan oleh Aice.

\section{Promotions (promosi)}

Melalui pemasaran media sosial, dapat memberikan diskon eksklusif dan kesempatan bagi audience untuk membuat mereka merasa dihargai dan khusus, serta untuk memenuhi tujuan jangka pendek. Aice selalu membagikan informasi kepada follower-nya melalui Instagram feed setiap ada promosi diskon di minimarket, supermarket, maupun hypermarket tertentu, dan selalu mendapatkan respons positif dari follower-nya melalui kolom komentar.

5. Market research (riset pasar)

Media social dapat digunakan untuk mempelajari perilaku konsumen, kebutuhan dan keinginan konsumen, dan mempelajari competitor. Aice selalu melakukan market research salah satunya melalui aktivitas di instagramnya untuk selalu mengembangkan produk dan kegiatan komunikasi pemasarannya.

Berdasarkan penjelasan di atas media sosial adalah suatu alat digital marketing yang dapat menjangkau semua kalangan, dengan biaya yang relatif terjangkau atau tidak menggunakan biaya sama sekali dan digunakan untuk menciptakan suatu komunitas, membangun hubungan, dan bertukar informasi dengan sesama pengguna media sosial dalam jangka waktu yang tidak terbatas. Aice telah memanfaatkan e-WOM dengan sangat baik melalui media sosial yang dimilikinya, terutama Instagram.

\section{SIMPULAN}

Aice sebagai produsen baru di bidang es krim telah berhasil meraih perhatian konsumen hanya dalam waktu singkat, yaitu empat tahun sehingga mampu mendapatkan TOP Brand For Kids 2019 bersama dua merek es krim yang telah sangat lama popular di Indonesia, bahkan mengalahkan beberapa merek es krim yang telah lama beredar di Indonesia, serta merek es krim baru lainnya di pasaran Indonesia. Aice telah menggunakan media sosialnya, salah satunya instagram sebagai sarana yang tepat dan efektif sebagai salah satu upaya kegiatan bauran komunikasi pemasarannya. Aktivitas yang terjadi di Instagram @aiceindonesia telah memenuhi semua tindakan untuk meningkatkan WOM menurut Peters, Morris, Heckman, dan Dye (Mason, 2008:89). Selain semua tindakan yang dilakukan, pemasar juga harus mampu untuk selalu aktif berinteraksi dengan 
follower-nya di media sosial, menjawab setiap comment dan DM dari follower, serta menggunakan bahasa sehari-hari yang mudah dipahami oleh konsumen.

Aktivitas yang dilakukan Aice juga telah memenuhi lima tujuan dari social media marketing menurut Guneluis (Guneluis, 2011:15) yaitu relationship building, brand building, publicity, promotions, dan market research. Marketing komunikasi menggunakan e-WOM terbukti cocok digunakan untuk bisnis baru sebagai pengenalan produk dan pembentukan brand awereness kepada masyarakat seperti yang dilakukan es krim Aice. Strategi e-WOM yang dilakukan oleh Aice dapat dicontoh oleh produk lain yang ingin meningkatkan brand awareness produknya secara cepat dan efektif.

\section{DAFTAR PUSTAKA}

Basarani, S. (2011). Electronic Word of Mouth: Managing Online Guest Reviews in Hospitality Industry. Swedia: Jurnal Internasional Universitas Sodertorns.

Devito, J. A. (2011). Komunikasi Antar Manusia. Pamulang: Karisma Publishing Group.

Gruen,T.W., Osmonbekov,T.,Czaplewski,A.J. (2006). eWOM: The Impact of Customer-toCustomer Online Know- how Exchange On Customer Value and Loyalty, Journal of BusinessResearch, 59(4): 449-456.

Gunelius, Susan. (2011). 30-Minute Social Media Marketing. United States: McGraw-Hill Companies.

Hennig- Thurau, Thorsten, Kevin P. Gwinner, Gianfranco Walsh, dan Dwayne D. Gremler. (2004). Electronic Word-of -Mouth via Consumer-Opinion Platforms: What Motivates Consumers to Articulate Themselves on the Internet?. Journal of Interactive Marketing, 18 (1): 38-52.

Jalilvand, M. R. dan Samiei, N. (2012). The Effect of Electronic Word of Mouth on Brand Image and Purchase Intention. An Empirical Study in the Automobile Industry in Iran. Marketing Intellegence and Planning, 30 (4):460-476.

Jeong, E. dan Jang, Soo Cheong (Shawn). (2011). Restaurant Experience Triggering Positive Electronic Word-of-Mouth (e-WOM) Motivations. International Journal of Hospitality Management, 30:356-366.

Kotler, P. dan Amstrong. (2004). Dasar-Dasar Pemasaran Edisi Sembilan Jilid 1. Jakarta: Indeks.

Kotler, Philip dan Keller, Kevin Lane. (2009).
Manajemen PemasaranEdisi 13 Jilid 1. Jakarta:Indeks.

Mason, R. B. (2008). Word of Mouth As a Promotional Tool for Turbulent Markets. Journal of Marketing Communication: 207224.

Mathis, Robert L. dan Jackson, John H. (2011). Human Resource Management Edisi 10. Jakarta: Salemba Empat.

Moelong , L. J. (2008). Metode Penelitian Kualitatif. Bandung: PT. Remaja Rosda Karya.

Mulyana, D. (2004). Metodologi Penelitian Kualitatif. Bandung: PT Remaja Rosdakarya.

Sugiyono. (2005). Metode Penelitian Administrasi. Bandung: Alfabeta. 